\title{
Removal of crystal violet dye by adsorption using bentonite - alginate composite
}

\author{
Rizka Fabryanty $^{\mathrm{a}, 1}$, Chrissila Valencia ${ }^{\mathrm{a}, 1}$, Felycia Edi Soetaredjo ${ }^{\mathrm{a}, *}$, Jindrayani Nyoo Putro ${ }^{\mathrm{b}}$, \\ Shella Permatasari Santoso ${ }^{\mathrm{a}}$, Alfin Kurniawan ${ }^{\mathrm{b}}$, Yi-Hsu Ju ${ }^{\mathrm{b}}$, Suryadi Ismadji,** \\ a Department of Chemical Engineering, Widya Mandala Surabaya Catholic University, Kalijudan 37, Surabaya 60114, Indonesia \\ ${ }^{\mathrm{b}}$ Department of Chemical Engineering, National Taiwan University of Science and Technology, Taipei, Taiwan
}

\section{A R T I C L E I N F O}

\section{Keywords:}

Alginate

Bentonite

Composite

Adsorption

Crystal violet

\begin{abstract}
A B S T R A C T
The microwave rapid heating method was successfully applied to the production of bentonite - alginate composite which is effectively used as a sorbent for dye removal. The irradiation method has been proven to assist effectively in the formation of sorbent pores that facilitate the permeation of dye solution. Three nanocomposite models were prepared by varied the mass of bentonite to a certain mass of sodium alginate. In this study, the adsorption performance of bentonite - alginate nanocomposites were tested for the removal of crystal violet dye. The characterizations of the composites were conducted using Fourier Transform Infrared Spectroscopy (FTIR), Scanning Electron Microscopy (SEM), X-Ray Diffraction (XRD), and nitrogen sorption methods The adsorption experiments were carried out in batch mode at three different temperatures $\left(30,50\right.$, and $\left.70{ }^{\circ} \mathrm{C}\right)$. The adsorption equilibria data were fitted by Langmuir and Freundlich isotherms. The nonlinear fitting coefficient $R^{2}$ indicates that the adsorption follows both the isotherm models well. The best adsorption capacity is showed by the composite prepared with the highest proportion of bentonite mass. The high-temperature promotes the adsorption capacity of the composite, where at $70{ }^{\circ} \mathrm{C}$ the adsorption capacity is reached $601.9339 \mathrm{mg} / \mathrm{g}$ (Langmuir parameter, $q_{\max }$ ) or $36.3399(\mathrm{mg} / \mathrm{g})(\mathrm{L} / \mathrm{mg})^{-\mathrm{n}}$ (Freundlich parameter, $\left.K_{F}\right)$. The adsorption kinetic results follow the pseudo-second-order model better than the pseudo-first-order which indicated by higher $R^{2}$ values $(0.9209$ to 0.9916$)$. As indicated by the thermodynamic properties, the adsorption process is controlled by chemisorption.
\end{abstract}

\section{Introduction}

Some industrials such as textiles, ceramics, papers, and printing are known as the industries that use significant amounts of dye to color their products [1-4]. During the coloring process, some amount of dyes are absorbed in the product, and some of them will end up in the wastewater. Currently, thousands of synthetic dyes are available in the market. Some of them are safe to human and can be used to color food and beverage, but some of them are harmful or even dangerous to human health. Among these dyes, crystal violet is one kind of dyes which possess adverse effects to human health. It may cause eye burn leading to permanent cornea/eye damage. Its inhalation gives rise to a short period of rapid or difficult breathing, nausea, vomiting, profuse sweating, hypermotility, diarrhea, and abdominal pain [1].

Depending on its application, some of the synthetic dyes are designed to be chemically or biologically resistant, and the presence of these kinds of dyes in the environment can cause severe environmental problems. The persistent of this type of dyes in the environment due to its complex chemical structure, they are resistant to breakdown by chemical, physical and biological treatments [5]. The existence of dye (such as crystal violet) in a water body, even in just $1 \mathrm{ppm}$ in concentration, is highly visible and often disturbs the photosynthesis process of water plants due to the blockage of the penetration of sunlight in the water [6]. Crystal violet dye at the level of $1 \mathrm{ppb}$ is said to be toxic and possibly mutagenic to human and animals [7]. Therefore, proper treatments are required to remove these pollutants from wastewater before discharging into the environment.

There are many methods available to treat wastewater containing dyes such as physical treatment including adsorption, membrane filtration, ionexchange and electrochemical techniques [8-11]; physicochemical treatment including coagulation and flocculation, reverse osmosis, chemical oxidation, ozonation [11-14]; biological treatment including activated sludge, bacterial action $[15,16]$. Among those methods, adsorption is more promising than the other methods due to its economic, flexibility, and

\footnotetext{
* Corresponding authors.

E-mail addresses: felyciae@yahoo.com (F.E. Soetaredjo), alfin_kur@yahoo.com (A. Kurniawan), suryadiismadji@yahoo.com (S. Ismadji).

${ }^{1}$ These authors contributed equally.
} 
efficiency of the process. The effectiveness of the adsorption process for dyes removal strongly depends on the adsorbent used. Several commercially available adsorbents have high adsorption capability such as activated carbon. However, the main obstacles to using activated carbon as the adsorbent for wastewater treatment is its price. An emerging dye removal method, the photocatalytic degradation, promises an environmentally friendly and sustainable process. In this process, the presence of a catalyst is required to convert light into energy; the generated energy will then initiate the formation of reactive species which are responsible for degrading the dyes. The catalyst used is prepared by using photo-anode metal oxide material, such as $\mathrm{TiO}_{2}, \mathrm{ZnO}, \mathrm{SnO}_{2}$, and $\mathrm{ZrO}_{2}$. Even though the light is an inexpensive energy source, however, the process itself is impractical and required expensive equipment, only effective for the small amount of dyes, and have the possibility to generate harmful reactive oxidating species (ROS) [17-19]. Some magnetic metal oxide powders (such as $\mathrm{Fe}_{2} \mathrm{O}_{3}, \mathrm{Fe}_{3} \mathrm{O}_{4}$, and $\mathrm{Al}_{2} \mathrm{O}_{3}$ ) are known as potential adsorbents. The removal method by using metal oxide depends on the sequestering ability of the dye to form complexes with metal [20-24]. However, similar to photocatalytic process, the magnetic metal oxides may initiate the formation of ROS. Therefore, the efficient adsorption process by using in-expensive adsorbent which is not generating ROS still becomes a trending topic.

In this study, a new adsorbent was synthesized from clay mineral and natural polymer, namely bentonite and alginate. A fast and easy method involving microwave irradiation was employed for bentonite alginate composite preparation. This microwave irradiation method is efficient in heating the molecules of the materials (bentonite and alginate) by introducing high radiation energy. The heated molecules are rapidly moved and collided each other as the result of the high-energy inducement; this phenomenon will help the molecules to incorporate each other. The adsorption capability of the composites was tested to remove crystal violet dye (cationic dye) from aqueous solution.

\section{Materials and methods}

\subsection{Materials}

Crystal violet dye (CI $=42555$, dye content $\geq 90 \%$, molecular formula $\mathrm{C}_{25} \mathrm{H}_{30} \mathrm{ClN}_{3}$, MW 407.99 and $\lambda_{\max }=590 \mathrm{~nm}$ ) was obtained from Merck (Merck Co., Germany). Bentonite was supplied from Pacitan, East Java, Indonesia. Sodium alginate was purchased from CV. Nura Jaya, Surabaya, Indonesia. Hydrochloric acid $(\mathrm{HCl})$, sodium hydroxide $(\mathrm{NaOH})$, calcium chloride $\left(\mathrm{CaCl}_{2}\right)$ were purchased as an analytical grade from Merck (Merck Co., Germany). All chemicals were used without any further purification.

\subsection{Acid activation of bentonite}

The initial moisture content of the bentonite utilized in this study was around $30 \%$ (was obtained directly from the bentonite mining located in Pacitan, East Java, Indonesia). Reproducibility of the experiments was maintained by uniforming the initial moisture content of the raw bentonite to $10 \%$. Subsequently, for pretreatment, the dried bentonite was pulverized until its particle size $-100 /+120$ mesh. The bentonite was pretreated using a modified acid activation method [25]. Bentonite was activated by immersing into the $5 \mathrm{~N}$ of $\mathrm{HCl}(1: 10 \mathrm{w} / \mathrm{v}$ ratio) solution. During the activation process, the mixture was kept under a constant mechanical stirring at $200 \mathrm{rpm}$. The temperature of the activation process was maintained at $60{ }^{\circ} \mathrm{C}$ for $2 \mathrm{~h}$. The resulting acid - activated bentonite was filtered and rinsed with deionized water and dried in an oven (Memmert UM 400) at $105^{\circ} \mathrm{C}$. To homogenize the particle size of purified bentonite, bentonite was crushed and screened to obtained smaller particle size $-180 /+200$ mesh. Finally, the acidactivated bentonite was kept in a desiccator until further use. The choice of the parameters (time of activation, temperature, type of acid, and the ratio of acid) for bentonite activation was based on our preliminary experiments. In our preliminary experiments we chose several variables of the process (time of activation: 1,2 , and $3 \mathrm{~h}$; temperature: 40,50 , and $60{ }^{\circ} \mathrm{C}$; type of acid: $\mathrm{H}_{2} \mathrm{SO}_{4}$ and $\mathrm{HCl}$; and the ratio of acid $\mathrm{w} / \mathrm{v}$ : 1:1, 1:10, 1:15). The adsorption capacities of acid activated bentonites which prepared under different variation parameters were tested for the adsorption of crystal violate dye, and the parameters that produce acid activated bentonite with the highest adsorption capacity was chosen for subsequent experiments.

\subsection{Preparation of bentonite-alginate composite}

A $2 \%(\mathrm{w} / \mathrm{v})$ of sodium alginate solution was prepared by mixing $2 \mathrm{~g}$ of sodium alginate with $100 \mathrm{~mL}$ of deionized water, and then bentonite clay was added to the solution. The ratio of bentonite clay/sodium alginate were $2: 5 ; 3: 5 ; 4: 5 \mathrm{w} / \mathrm{w}$. As for the simplification purpose, the composites were designated as $2 \mathrm{~B}: 5 \mathrm{~A}, 3 \mathrm{~B}: 5 \mathrm{~A}$, and $4 \mathrm{~B}: 5 \mathrm{~A}$ for the mass ratio of bentonite (B) to sodium alginate (A) of 2:5; 3:5; $4: 5 \mathrm{w} / \mathrm{w}$ respectively.

The mixture was stirred under constant stirring at $500 \mathrm{rpm}$ for $3 \mathrm{~h}$ at $50{ }^{\circ} \mathrm{C}$. Subsequently, the mixture was irradiated in a microwave oven at $700 \mathrm{~W}$ for $90 \mathrm{~s}$. After the formation of composite completed, the homogeneous mixture was dropped (using pipette) to $1 \%(\mathrm{w} / \mathrm{v})$ calcium chloride solution to form gel spheres. The excess of calcium chloride solution was separated from the beads by washing with deionized water at least three times and dried in an oven (Memmert UM 400) at $50{ }^{\circ} \mathrm{C}$ for $24 \mathrm{~h}$. The resulting dried bentonite-alginate nanocomposite was stored in a clean container and kept in a desiccator until further use.

\subsection{Characterization}

The characterization of acid - activated bentonite and bentonite alginate composites was conducted using Fourier Transform Infrared spectroscopy (FTIR), X-Ray diffraction (XRD), scanning electron microscopy (SEM), and nitrogen sorption methods. FTIR analysis of the bentonite, alginate, bentonite-alginate nanocomposite was carried out using a Shimadzu/FTIR-8400S spectrometer with $\mathrm{KBr}$ pellets from 400 to $4000 \mathrm{~cm}^{-1}$. The surface morphologies of acid-activated bentonite and bentonite - alginate nanocomposites were obtained using Scanning Electron Microscopy. The surface analysis was carried out on a JEOL JSM-6500F field emission SEM at $15 \mathrm{kV}$. Before SEM analysis, the samples were coated with a thin layer of platinum $(3 \mathrm{~nm})$. The coating process was conducted for $90 \mathrm{~s}$ in argon atmosphere using a fine auto coater (JFC-1600, JEOL, Ltd., Japan).

XRD analysis of bentonite and composites was carried out using a Philips X'pert Xray Diffractometer. The XRD patterns were obtained at $40 \mathrm{kV}$ and $30 \mathrm{~mA}$ and monochromatic high-intensity $\mathrm{Cu} \mathrm{Ka} 1$ $(\lambda=0.15405 \mathrm{~nm})$ was used as the source of radiation. The nitrogen sorption isotherms of the samples were obtained at a temperature of $-176{ }^{\circ} \mathrm{C}$ and relative pressure $\left(p / p^{o}\right)$ of 0.001 to 0.999 using Micromeritics ASAP 2010 sorption analyzer. Before the nitrogen sorption measurement, all samples were degassed at $150{ }^{\circ} \mathrm{C}$ in a vacuum condition for $24 \mathrm{~h}$. The standard Brunauer-Emmett-Teller (BET) equation was applied for the determination of the BET surface area $[26,27]$. Total pore volume was calculated at a pressure where all pores were filled with nitrogen gas, approximately at a $p / p^{o} 0.999$.

The $\mathrm{pH}$-drift procedure was used to determine the point of zero charges $\left(\mathrm{pH}_{\mathrm{Pzc}}\right)$ of adsorbents [28]. A stock solution of $0.01 \mathrm{~N} \mathrm{NaCl}$ was prepared. The solution was then poured into a series of conical flasks ( $50 \mathrm{~mL}$ each), the $\mathrm{pH}$ of each flask was varied from 2 to 10 . Adjustment of $\mathrm{pH}$ was done by using $0.1 \mathrm{~N} \mathrm{NaOH}$ or $\mathrm{HCl}$ solutions. $0.2 \mathrm{~g}$ of adsorbent was then added to each flask and shaken at room temperature for $48 \mathrm{~h}$. The initial and final $\mathrm{pH}$ of the solution was measured by using a digital $\mathrm{pH}$-meter (Schott CG-825). The $\mathrm{pH}_{\mathrm{Pzc}}$ is determined as the $\mathrm{pH}$ where the curve of $\mathrm{pH}_{\text {final }}$ vs $\mathrm{pH}_{\text {initial }}$ crosses the line when $\mathrm{pH}_{\text {final }}=\mathrm{pH}_{\text {initial. }}$. 


\subsection{Adsorption experiment}

The adsorption kinetic study of crystal violet onto bentonite, sodium alginate and bentonite-sodium alginate composites was conducted at $30{ }^{\circ} \mathrm{C}$. A liter of crystal violet dye stock solution with an initial concentration of $300 \mathrm{mg} / \mathrm{L}$ was prepared and poured into a series of Erlenmeyer flasks, each containing $50 \mathrm{~mL}$ solution. The specific amount of adsorbent $(0.5 \mathrm{~g})$ was added to each flask. The flasks were shaken at $100 \mathrm{rpm}$ in a Memmert water bath for certain period of times. After certain time reached, the remaining crystal violet dye solution was measured by using a spectrophotometer.

The adsorption isotherm study was conducted in a batch process at three different temperatures $\left(30,50\right.$, and $\left.70^{\circ} \mathrm{C}\right)$. The adsorption isotherm study was carried out by adding various amounts of adsorbent $(0.1-1 \mathrm{~g})$ into a series of Erlenmeyer flasks, each containing $50 \mathrm{~mL}$ of crystal violet dye solution with an initial concentration of $300 \mathrm{mg} / \mathrm{L}$. The flasks were shaken at $100 \mathrm{rpm}$ until the equilibrium condition was reached, then the solid was separated from the solution by centrifugation at $5000 \mathrm{rpm}$ for $10 \mathrm{~min}$.

During all adsorption processes, the temperature of the system was controlled at desired temperature using thermal controller embedded in shaking water bath. The initial and equilibrium concentrations of the crystal violet in the solution were determined using a Shimadzu UV mini-1240 spectrophotometer. The amount of crystal violet adsorbed by the adsorbent at equilibrium condition $\left(Q_{e}, \mathrm{mg} / \mathrm{g}\right)$ was determined by the following equation:

$Q_{e}=\frac{C_{i}-C_{e}}{m} V$

Where $C_{i}$ and $C_{e}$ are the initial and equilibrium concentrations (mg/L), respectively, $V$ is the volume of solution (L), and $m$ is the mass of adsorbent (g). A calibration curve with a series of crystal violet concentration $(0-100 \mathrm{mg} / \mathrm{L})$ was prepared prior for the determination of initial and final dye concentration. The spectrum measurements were done with a wavelength of $590 \mathrm{~nm}$. Each set of the experiments was done in triplicate, the uncertainty in the measurement results was shown by the standard deviations which represented as error bars.

\section{Result and discussion}

The formation mechanism of bentonite-alginate composite is shown in Fig. 1. The composite was prepared by mixing the sodium alginate and bentonite in water. Subsequently, the mixture was irradiated by using the microwave. The composite was then cured by dropping in the $1 \%(\mathrm{w} / \mathrm{w}) \mathrm{CaCl}_{2}$. Silanol group of bentonite is readily protonated when immersing in the water; this causes a positive charge of the silanol group. Likewise, the $\mathrm{Na}^{+}$ion of sodium alginate is readily ionized when dissolving in the water, leading to a negative charge of the carboxyl group. The high energy of microwave will heat up the molecules of both materials and initiate the interaction between the positive charge

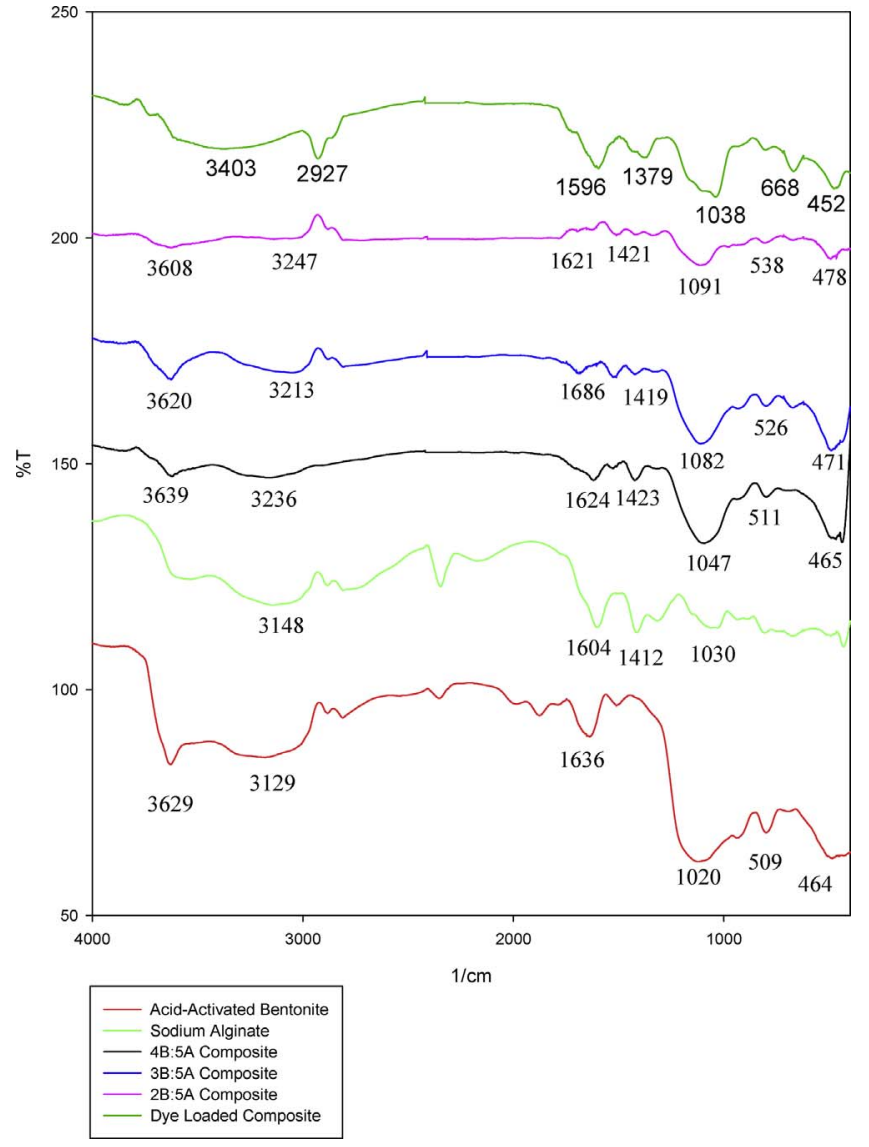

Fig. 2. Fourier Transform Infrared (FTIR) Spectra of adsorbents at range of $4000-400 \mathrm{~cm}^{-1}$.

silanol and negative charge carboxyl groups. The curing effect of the composite was then initiated by the $\mathrm{Ca}^{+}$ions of $\mathrm{CaCl}_{2}$.

\subsection{Characterization}

The surface functional groups of bentonite-alginate nanocomposites were obtained by Fourier Transform Infrared (FTIR) spectroscopy analysis. FTIR analysis was conducted to confirm the formation of the composited by comparing the alteration of a functional group on the surface of the composites, alginate, and bentonite. The alterations of the functional group before and after the adsorption of crystal violet were also observed. Fig. 2 shows the FTIR spectra of acid - activated bentonite, sodium alginate, and bentonite - alginate composites. Several surface functional

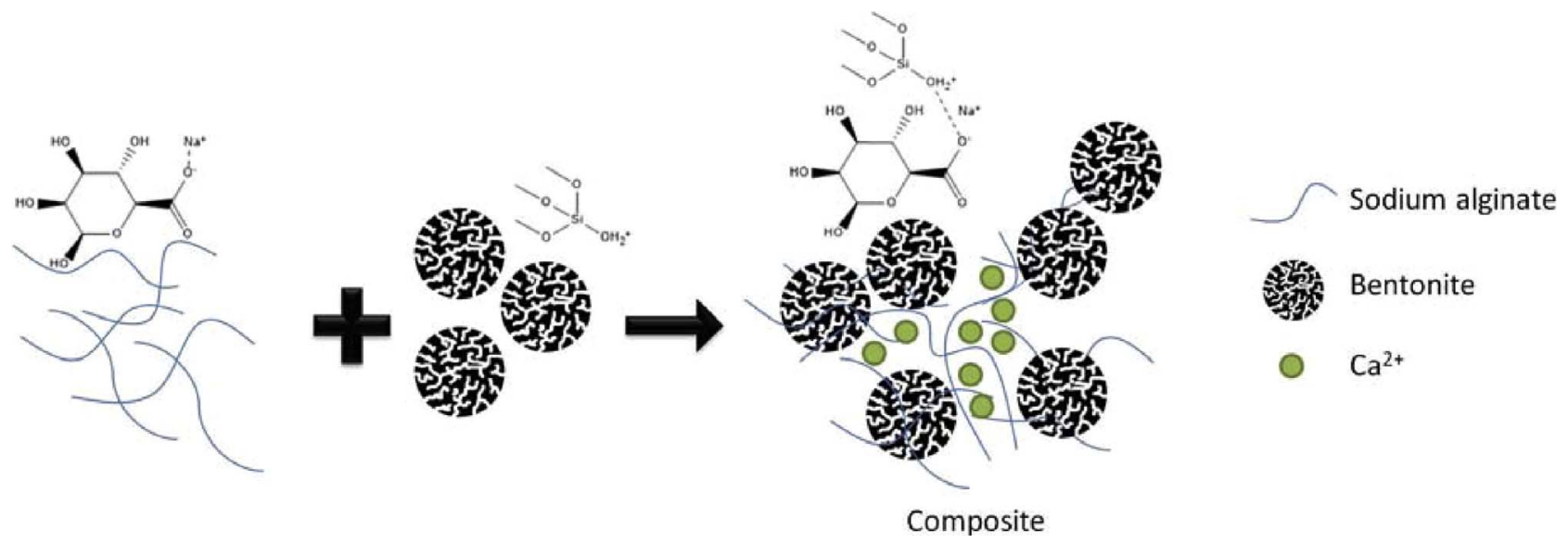

Fig. 1. The formation mechanism of bentonite-alginate composite. The composite was prepared at 3 different mass ratio of bentonite to alginate of $2: 5$, $3: 5$ and $4: 5$ w/w. 
Table 1

FT-IR Assignments of Bentonite, Alginate and Composites.

\begin{tabular}{|c|c|c|c|c|c|c|}
\hline \multirow[t]{2}{*}{ IR Assignments } & \multicolumn{5}{|c|}{ Wavenumber $(1 / \mathrm{cm})$} & \multirow[t]{2}{*}{ Literature } \\
\hline & Bentonite (B) & Alginate (A) & $2 \mathrm{~B}: 5 \mathrm{~A}$ & 3B:5A & 4B:5A & \\
\hline (Si,Al)-OH stretching & 3629 & - & 3608 & 3620 & 3639 & $3600-3700$ \\
\hline -OH stretching & 3129 & 3148 & 3247 & 3213 & 3236 & $3200-3600$ \\
\hline $\mathrm{COO}^{-}$stretching & 1636 & 1604 & 1621 & 1686 & 1624 & $1500-1800$ \\
\hline $\mathrm{CH}_{2}$ bending vibration & - & 1412 & 1421 & 1419 & 1423 & $1400-1500$ \\
\hline R-O-R stretching & 1020 & 1030 & 1091 & 1082 & 1047 & $1050-1100$ \\
\hline \multirow[t]{2}{*}{$-\mathrm{OH}$ vibration } & 509 & - & 538 & 526 & 511 & $400-600$ \\
\hline & 464 & - & 478 & 471 & 465 & \\
\hline
\end{tabular}

groups found in acid - activated bentonite are as follow: hydroxyl stretching of ( $\mathrm{Si}, \mathrm{Al})-\mathrm{OH}\left(3629 \mathrm{~cm}^{-1}\right)$, hydroxyl stretching of $\mathrm{H}-\mathrm{O}-\mathrm{H}$ (3192 $\mathrm{cm}^{-1}$ ), hydroxyl bending of $\mathrm{H}_{2} \mathrm{O}$ deformation vibration due to adsorbed water $\left(1636 \mathrm{~cm}^{-1}\right)$, Si-O-Si stretching $\left(1020 \mathrm{~cm}^{-1}\right), \mathrm{Al}-\mathrm{OH}$ (916 and $643 \mathrm{~cm}^{-1}$ ), Si-O bending vibrations $\left(509 \mathrm{~cm}^{-1}\right.$ ) [29].

The broadband around $3148 \mathrm{~cm}^{-1}$ in the FTIR spectrum of sodium alginate (Fig. 2) is correlated with $\mathrm{O}-\mathrm{H}$ stretching, while the peaks appearing at 1604 and $1412 \mathrm{~cm}^{-1}$ are associated with asymmetric and symmetric stretching vibrations of free carboxyl groups, respectively. The peak observed at $1030 \mathrm{~cm}^{-1}$ was attributed to the stretching of $\mathrm{C}-\mathrm{O}-\mathrm{C}$. The characteristic peaks for both of bentonite and sodium alginate are found in all composites as summarized in Table 1. Alteration some characteristic peaks of both raw materials are observed in composites such as $(\mathrm{Si}, \mathrm{Al})-\mathrm{OH}$ group $\left(3608-3639 \mathrm{~cm}^{-1}\right),-\mathrm{OH}$ vibration of bentonite $\left(465-538 \mathrm{~cm}^{-1}\right)$.

The peaks for $\mathrm{COO}^{-}$stretching, $\mathrm{CH}_{2}$ bending vibration and $\mathrm{R}-\mathrm{O}-\mathrm{R}$ stretching for the composites were shifted from the original peaks shown for alginate and bentonite. The $\mathrm{COO}^{-}$stretching for alginate observed at $1604 \mathrm{~cm}^{-1}$ and in bentonite at $1636 \mathrm{~cm}^{-1}$, shifted to $1621-1686 \mathrm{~cm}^{-1}$ for composites. The $\mathrm{CH}_{2}$ bending for alginate is observed at $1412 \mathrm{~cm}^{-1}$, shifted to $1419-1423 \mathrm{~cm}^{-1}$ for composite. The $\mathrm{R}-\mathrm{O}-\mathrm{R}$ stretching for alginate is $1030 \mathrm{~cm}^{-1}$ and for bentonite is $1020 \mathrm{~cm}^{-1}$, shifted to $1047-1091 \mathrm{~cm}^{-1}$ for all composites. The shift in the peak for $\mathrm{COO}^{-}$is indicated the electrostatic interaction between the negative charge carboxyl group of sodium alginate and the positive charge on the surface of bentonite [30-32]. Thus, the FTIR spectra of sodium alginate-bentonite composite confirmed the interaction between alginate and bentonite.

The X-Ray Diffraction (XRD) patterns for sodium alginate, acid activated bentonite, and composites are given in Fig. 3. XRD analysis was conducted to observe the change in the degree of crystallinity caused by the merging between alginate and bentonite. Sodium alginate

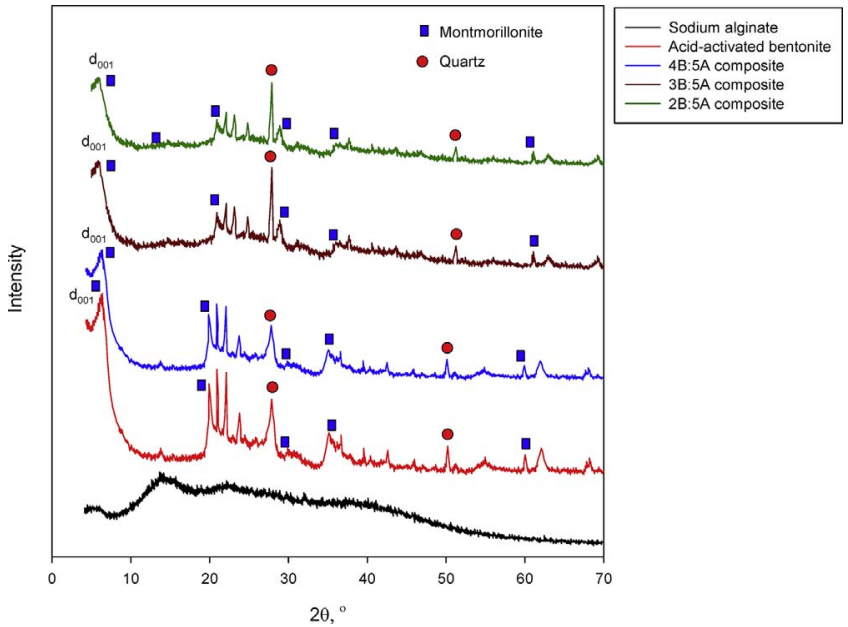

Fig. 3. X-Ray Diffraction (XRD) analysis of sodium alginate, acid activated bentonite, and composites. has an amorphous structure as seen in the XRD pattern (Fig. 3). Some characteristic peaks of montmorillonite were observed in XRD pattern of acid - activated bentonite $(2 \theta=6.44,20.18,30.06,35.28$, and $60.25^{\circ}$ ). The basal spacing of acid - activated bentonite at $2 \theta=6.44$ corresponds to $d_{001}=1.37 \mathrm{~nm}$. After encapsulation with sodium alginate to form the composites, the value of $\mathrm{d}_{001}$ for all composites almost similar to the basal spacing of acid - activated bentonite. This phenomenon indicates that the alginate molecules did not intercalate to silicate layers of montmorillonite, the bonding between alginate and montmorillonite only through the electrostatic interaction between positively charged of montmorillonite with the carboxyl group of sodium alginate. This XRD result confirms the result of FTIR analysis.

The micrographs of acid-activated montmorillonite obtained by using scanning electron microscope (SEM), 4B:5A composite, 3B:5A composite, and 2B:5A composite are depicted in Fig. 4. SEM observation was conducted to compare the difference in surface morphology between alginate, bentonite, and composites. Obviously, the surface morphology of composites is different with acid - activated bentonite. The surface of acid - activated bentonite quite smooth and rigid, while the composites $3 \mathrm{~B}: 5 \mathrm{~A}$ and $2 \mathrm{~B}: 5 \mathrm{~A}$ display some porous structure. This porous surface is possibly facilitating the permeation of water into the structure of composites.

Fig. 5 depicts the nitrogen sorption isotherms of acid - activated bentonite and composites. Acid - activated bentonite has a combination between type I and type II isotherm with broad hysteresis loop. At low relative pressure $\left(p / p^{o}\right)$ the isotherm is type I indicated by rapid intake of nitrogen gas by the bentonite. As the pressure increases, the isotherm gradually increase until a certain relative pressure rapid increase of the intake of nitrogen gas is observed (type II). The broad hysteresis loop is considered as type $\mathrm{H}_{2}$ hysteresis. This hysteresis indicates that activation of natural bentonite with $5 \mathrm{~N} \mathrm{HCl}$ solution created some complex network of interconnected pores or interlayers with bottleneck and contractions [33]. The BET surface area of the samples was calculated at a relative pressure between 0.05 to 0.3 , while pore volume was determined at the highest relative pressure. The BET surface area and pore volume of acid - activated bentonite are $73.5 \mathrm{~m}^{2} / \mathrm{g}$ and $0.112 \mathrm{~cm}^{3} / \mathrm{g}$ respectively.

The nitrogen sorption of the composites is also given in Fig. 5. The BET surface area and pore volume of 4B:5A composites are $56.8 \mathrm{~m}^{2} / \mathrm{g}$ and $0.085 \mathrm{~cm}^{3} / \mathrm{g}$; while for composite $3 \mathrm{~B}: 5 \mathrm{~A}$ are $33.5 \mathrm{~m}^{2} / \mathrm{g}$ and $0.052 \mathrm{~cm}^{3} / \mathrm{g}$, and for composite $2 \mathrm{~B}: 5 \mathrm{~A}$ are $21.6 \mathrm{~m}^{2} / \mathrm{g}$ and $0.031 \mathrm{~cm}^{3} / \mathrm{g}$. The decrease of BET surface area and pore volume of the composites mainly due to less bentonite structure in the composite. The nitrogen sorption of composites are a combination type I, II, and IV with H3-H4 hysteresis loop.

\subsection{Effect of $p H$}

To study the surface charge behavior (anion or cation exchangeability) of all adsorbents (acid-activated bentonite, sodium alginate, and bentonite-alginate composite) in the solution, $\mathrm{pH}_{\mathrm{Pzc}}$ (point of zero charges) of all adsorbents were analyzed using the $\mathrm{pH}$-drift procedure. 
(a)

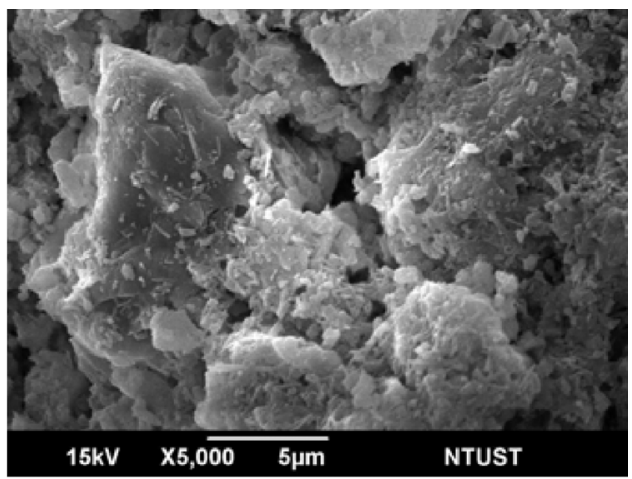

\section{(b)}

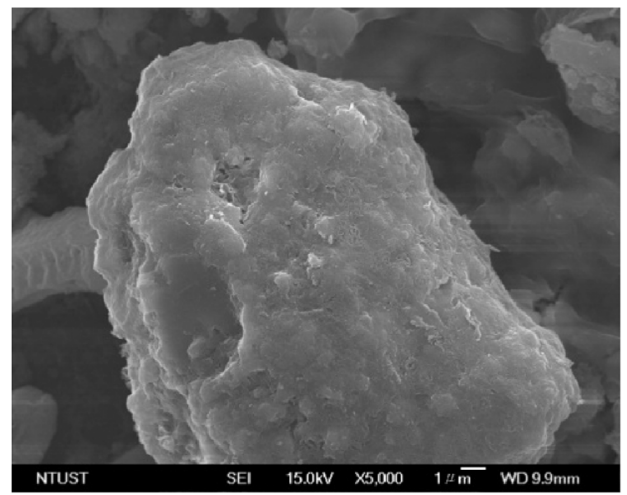

(c)

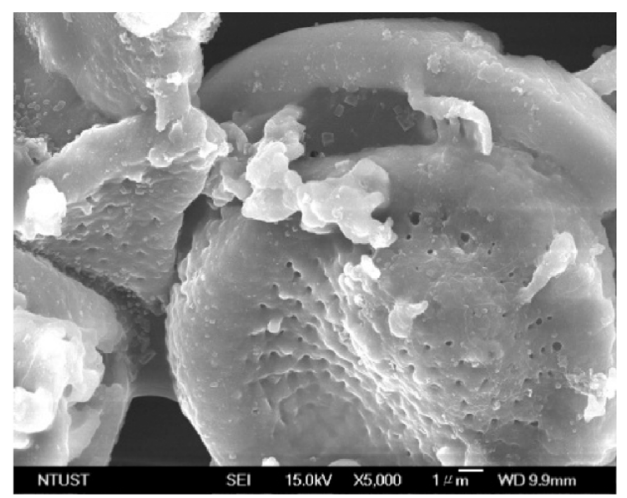

(d)

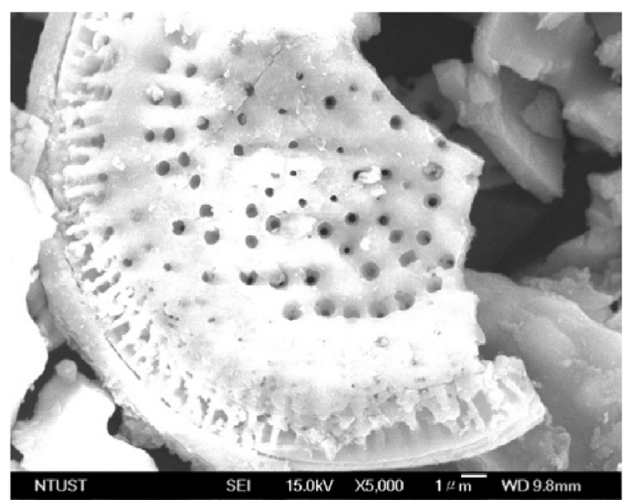

Fig. 4. SEM images of (a) bentonite, (b) 4B:5A composite, (c) 3B:5A composite, and (d) 2B:5A composite at same magnification of $15,000 \times$ and accelerating voltage of $15 \mathrm{kV}$.

The composites have a positive charge at $\mathrm{pH}$ less than $\mathrm{pH}_{\mathrm{pzc}}$, while at $\mathrm{pH}$ higher than $\mathrm{pH}_{\mathrm{pzc}}$ the composites possess a negative charge. The uptake of the crystal violet dye by the composites was strongly influenced by $\mathrm{pH}$ of the adsorption process.

The $\mathrm{pH}_{\mathrm{Pzc}}$ values for acid - activated bentonite was 3.88 , for sodium

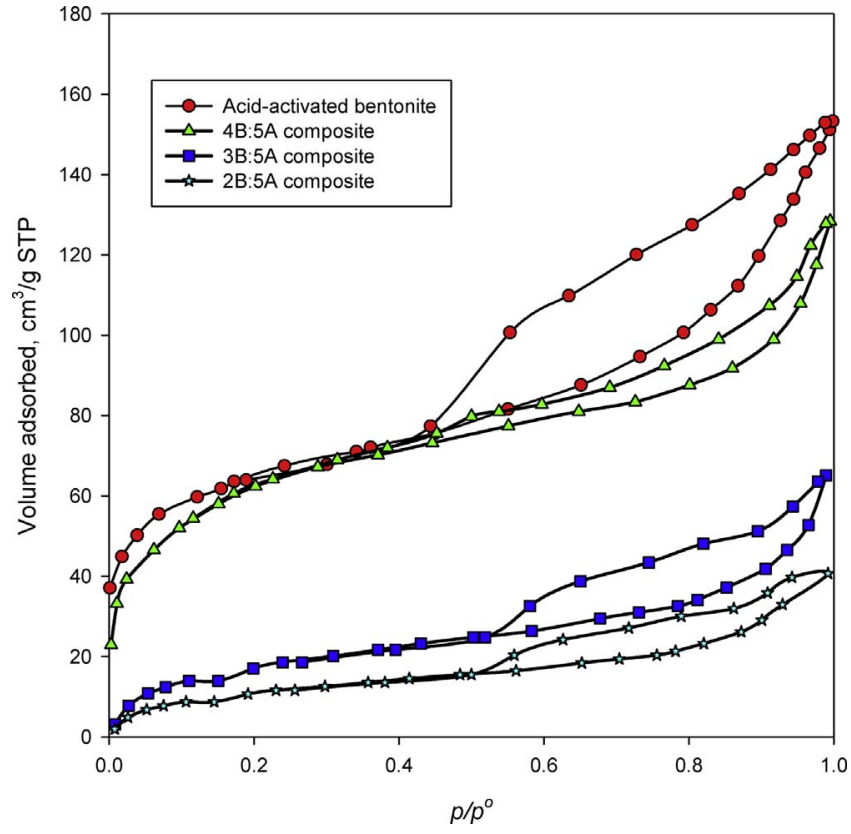

Fig. 5. Nitrogen sorption isotherm of acid-activated bentonite and composites.

alginate was 7.07, and for bentonite-alginate composites was 5 to 6 . The difference between the $\mathrm{pH}_{\mathrm{Pzc}}$ values is due to the difference in acidity of each adsorbent. A low $\mathrm{pH}_{\mathrm{Pzc}}$ indicates that the compound is acidic and easily protonated. The $\mathrm{pH}_{\mathrm{Pzc}}$ value is obtained when the adsorbents have a neutral charge. At acidic $\mathrm{pH}$ where $\mathrm{pH}<\mathrm{pH}_{\mathrm{Pzc}}$, the occurrence of excessive $\mathrm{H}^{+}$ions cause imbalance positive charge and leading to protonation of the adsorbents. Meanwhile at high alkaline $\mathrm{pH}$ where $\mathrm{pH}>\mathrm{pH}_{\mathrm{Pzc}}$, the excess $\mathrm{OH}^{-}$ions (originated from the addition of base) are cause the deprotonation of the $\mathrm{H}^{+}$. The deprotonation will lead to a negative charge of the adsorbents. The forms of protonated, neutral, and deprotonated species of each adsorbent were depicted in Supplementary data Figs. S1-S3.

The influence of $\mathrm{pH}$ on the adsorption of crystal violet onto adsorbents was studied at $\mathrm{pH}$ range of 3-9. The $\mathrm{pH}$ of the solution gave significant impact on the surface charges of the adsorbents; it is associated with the protonation and deprotonation of silanol groups at the active sites of bentonite and interaction with the negative carboxylate groups on alginate. The maximum uptake of crystal violet by bentonite, alginate, and composites were achieved at $\mathrm{pH} 4.1,8.9$, and 8.0, respectively. The removal percentage obtained at these pHs are $72.2 \%$, $81.5 \%, 87.6 \%, 93.5 \%$, and $97.8 \%$ for bentonite, alginate, composite 2B:5A, 3B:5A, and 4B:5A, respectively. The main reason for this outcome is that at $\mathrm{pH}$ above $\mathrm{pH}_{\mathrm{Pzc}}$, the adsorbent will tend to deprotonate. This will provide a negative charge on the surface of the adsorbent. The adsorption mechanism of crystal violet dye by composite at $\mathrm{pH}=\mathrm{pH}_{\mathrm{Pzc}}$ and $\mathrm{pH}>\mathrm{pH}_{\mathrm{Pzc}}$ is depicted in Supplementary data Fig. S4. The composite can adsorb more of crystal violet dye at $\mathrm{pH}>\mathrm{pH}_{\mathrm{Pzc}}$ because it has higher negative charge. Since crystal violet is a cationic dye, the interaction with a negative charge of a surface enhances the amount of dye adsorbed by the adsorbent due to the electrostatic interaction.

\subsection{Adsorption kinetic study}

The kinetic adsorption of crystal violet dye onto composites was studied at $30{ }^{\circ} \mathrm{C}$ with an initial concentration of $300 \mathrm{ppm}$. The wellknown kinetic models: pseudo-first order and pseudo second order equations were used to correlate the kinetic experiment data. The pseudo first order that also known as the Lagergren first-order rate expression based on the adsorbent capacity and is generally expressed as [34]: 
(a)

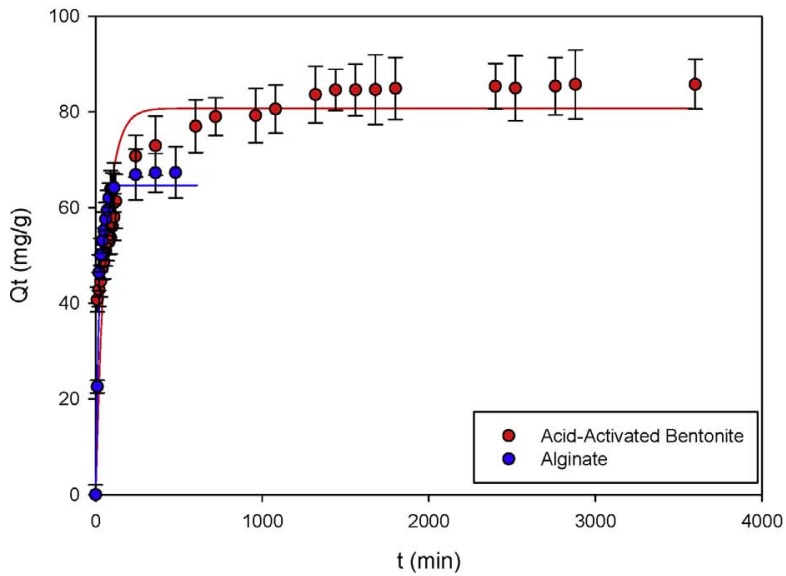

(b)

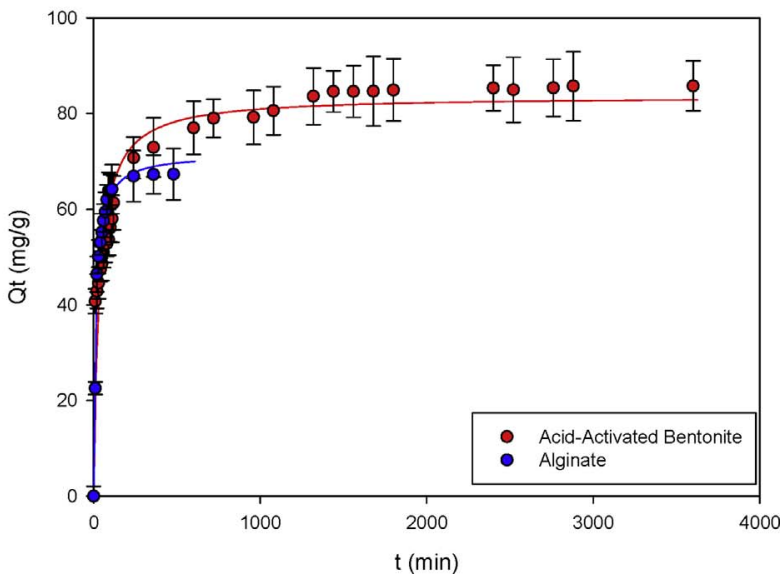

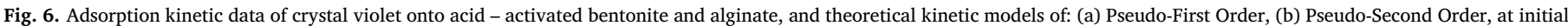

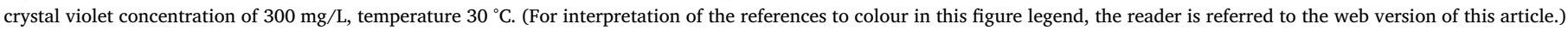

(a)

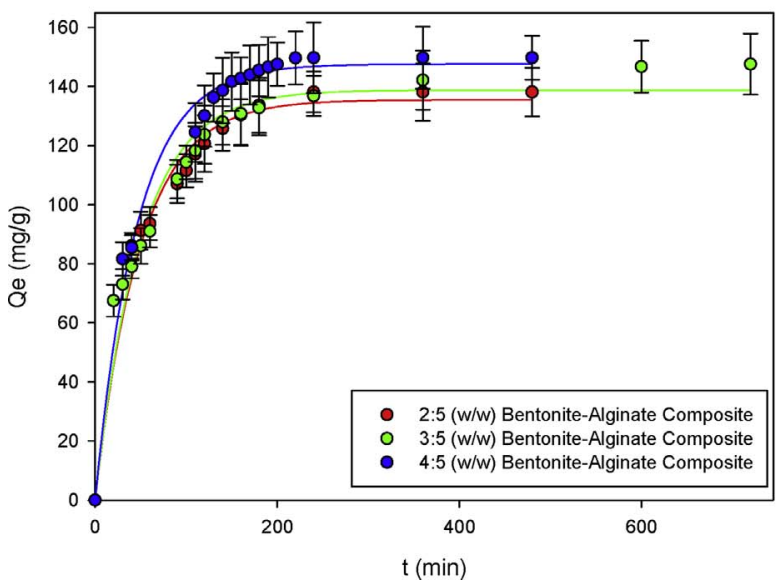

(b)

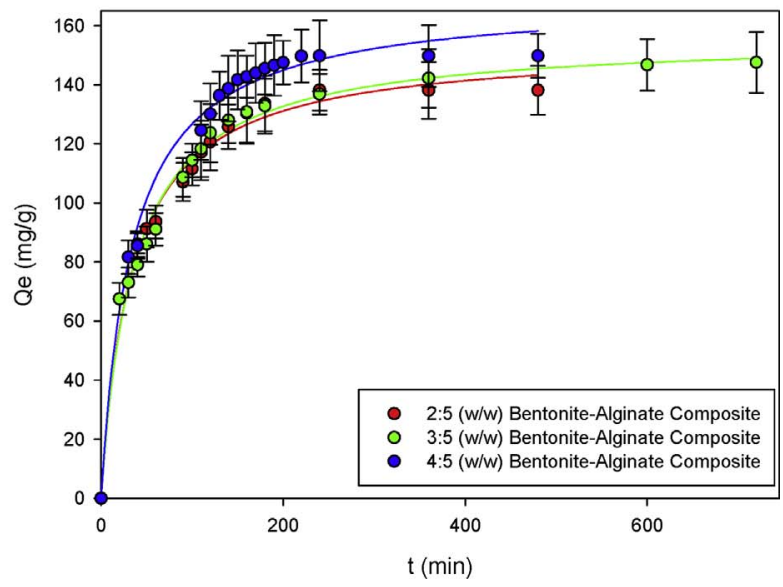

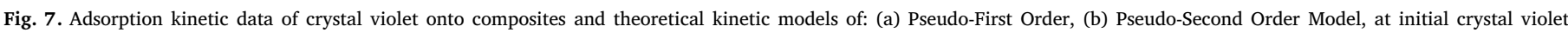
concentration of $300 \mathrm{mg} / \mathrm{L}$, temperature $30^{\circ} \mathrm{C}$. (For interpretation of the references to colour in this figure legend, the reader is referred to the web version of this article.)

$q_{t}=q_{e}\left(1-\exp \left(-k_{1} t\right)\right)$

The pseudo-second order assumes that chemisorption is dominant and controls the adsorption as rate-limiting step and it has the form:

$q_{t}=q_{e}\left(\frac{q_{e} k_{2} t}{1+q_{e} k_{2} t}\right)$

where $k_{1}\left(\mathrm{~min}^{-1}\right)$ and $k_{2}\left(\mathrm{~g} \mathrm{mg}^{-1} \mathrm{~min}^{-1}\right)$ are time scaling factor that indicates how much time needed to reach the equilibrium in the adsorption system, $q_{t}$ and $q_{e}$ are the amounts of crystal violet adsorbed $(\mathrm{mg} / \mathrm{g})$ at time $t$ and the equilibrium condition, respectively.

The adsorption kinetic study is necessary to provide the adsorption process mechanism based on its rate controlling steps that consolidate chemical reaction and mass transport. The experimental of the adsorption kinetic data and the theoretical calculation using pseudo-first and pseudo-second models are given in Figs. 6 and 7. In these figures, the experimental data are represented by the symbols while theoretical values of pseudo-first order and pseudo-second order are given in solid lines. The parameters of both of these equations are summarized in Table 2. As shown in Table 2, sodium alginate possesses larger rate constant $(k)$ of both kinetic models; this means that sodium alginate has smaller particle size thus the equilibrium condition is reached faster than other adsorbents. However, the parameter $q_{\mathrm{e}}$ indicates that at equilibrium condition, the amount of crystal violet adsorbed by sodium

Table 2

Pseudo-First-Order and Second-Order Parameters of Kinetic Adsorption between Crystal Violet at initial concentration of 300 mg/L with Bentonite, Alginate and Composites.

\begin{tabular}{|c|c|c|c|c|c|c|}
\hline \multirow[t]{2}{*}{ Adsorbents } & \multicolumn{3}{|c|}{ Pseudo First Order } & \multicolumn{3}{|c|}{ Pseudo Second Order } \\
\hline & $k_{1}\left(\min ^{-1}\right)$ & $q_{e}(\mathrm{mg} / \mathrm{g})$ & $R^{2}$ & $k_{2}\left(\mathrm{~g} / \mathrm{mg} \mathrm{min}{ }^{-1}\right)$ & $q_{e}(\mathrm{mg} / \mathrm{g})$ & $R^{2}$ \\
\hline Bentonite (B) & 0.0161 & 82.7693 & 0.8257 & 0.0004 & 83.6173 & 0.9209 \\
\hline Alginate (A) & 0.0474 & 64.6494 & 0.9784 & 0.0010 & 71.6565 & 0.9819 \\
\hline $2 \mathrm{~B}: 5 \mathrm{~A}$ & 0.0203 & 135.9726 & 0.9835 & 0.0002 & 153.3419 & 0.9916 \\
\hline 3B:5A & 0.0202 & 138.8209 & 0.9606 & 0.0002 & 156.2010 & 0.9883 \\
\hline $4 \mathrm{~B}: 5 \mathrm{~A}$ & 0.0217 & 147.6164 & 0.9875 & 0.0002 & 169.2418 & 0.9901 \\
\hline
\end{tabular}


(a)

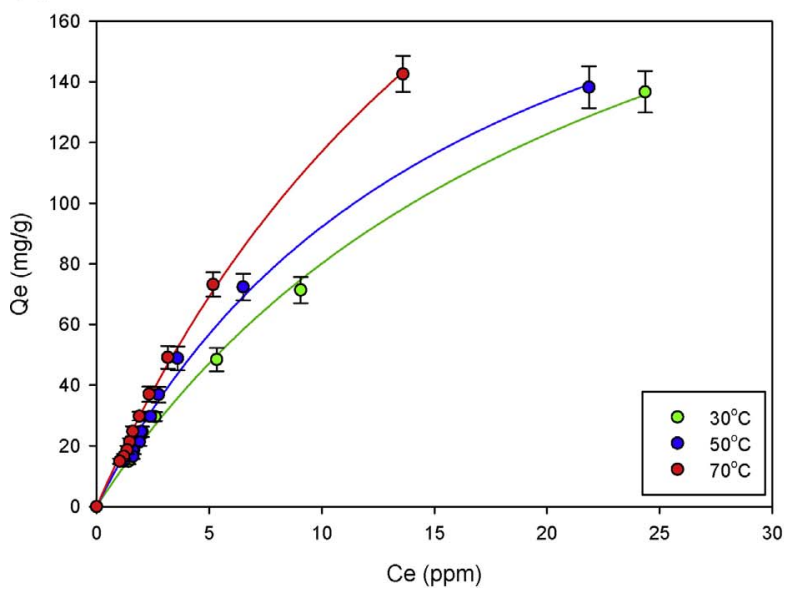

(b)

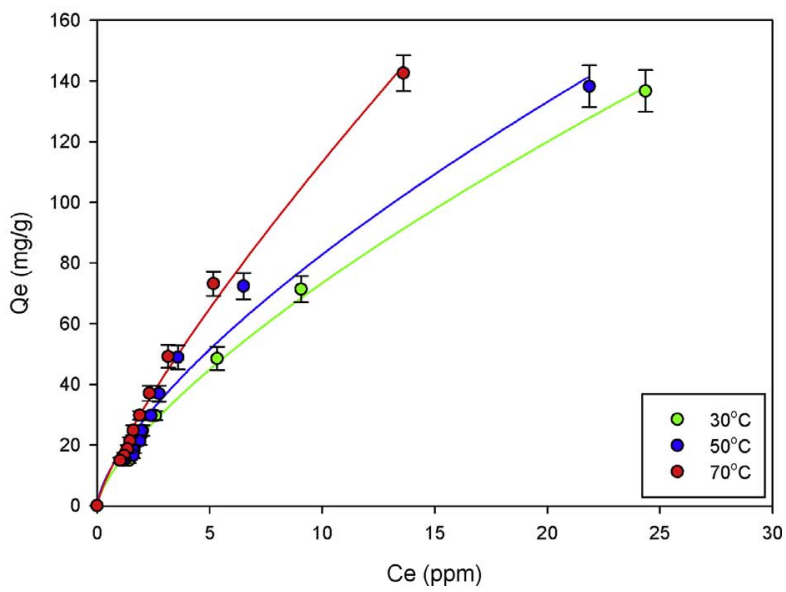

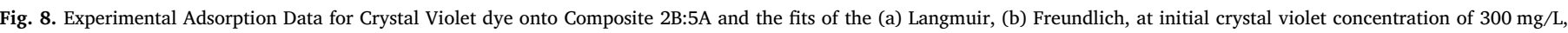
temperature 30,50 , and $70{ }^{\circ} \mathrm{C}$. (For interpretation of the references to colour in this figure legend, the reader is referred to the web version of this article.)

(a)

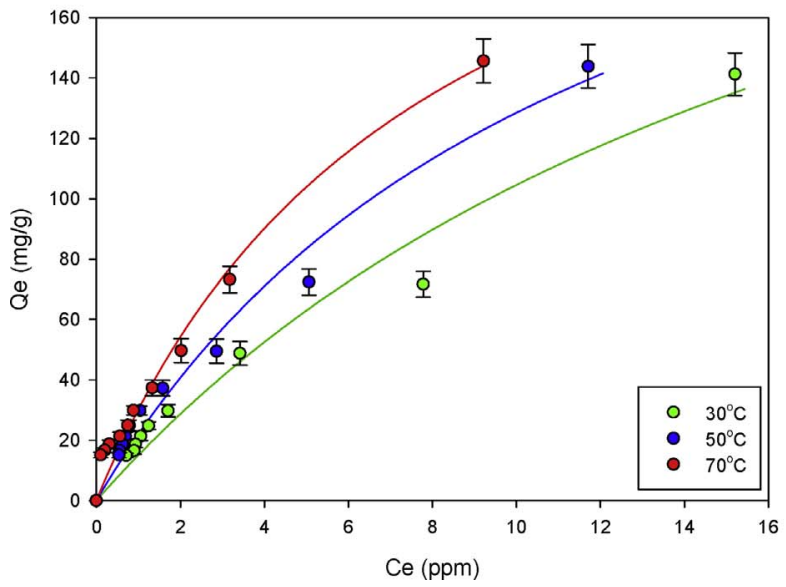

(b)

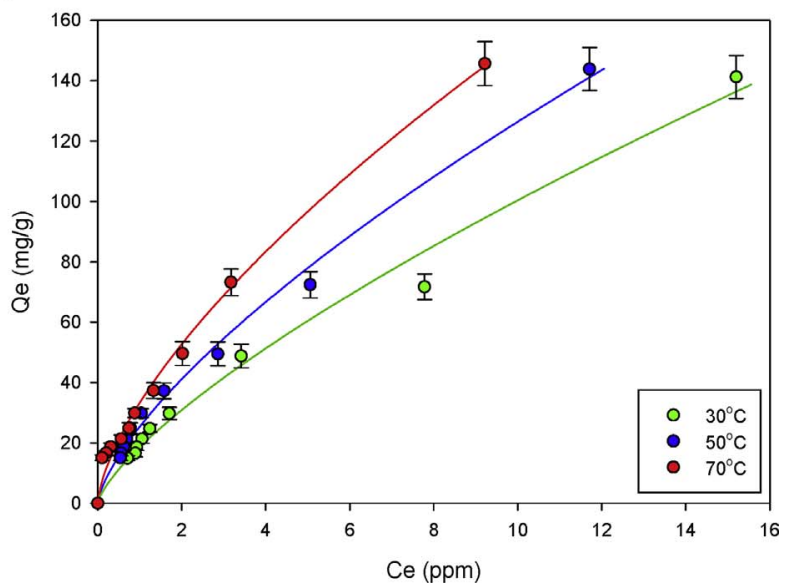

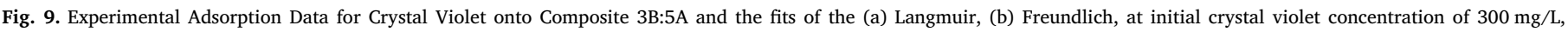
temperature 30,50 , and $70{ }^{\circ} \mathrm{C}$. (For interpretation of the references to colour in this figure legend, the reader is referred to the web version of this article.)

alginate is smaller than the other adsorbents. At equilibrium condition, the crystal violet dye is adsorbed at the most by composite $4 \mathrm{~B}: 5 \mathrm{~A}$ and then followed by 3B:5A, 2B:5A, bentonite, and alginate. The results indicate that the combination of bentonite-alginate gives a synergistic effect in the adsorption of crystal violet dye. The pseudo-second order model correlates the kinetic data better $\left(\mathrm{R}^{2}>0.9883\right)$ than pseudofirst order.

\subsection{Adsorption isotherm study}

The adsorption of crystal violet onto acid-activated bentonite, alginate, and composites were studied at temperatures of $30^{\circ} \mathrm{C}, 50^{\circ} \mathrm{C}$, and $70^{\circ} \mathrm{C}$ with the initial concentration of crystal violet of $300 \mathrm{mg} \mathrm{L}^{-1}$. The experimental adsorption data were correlated with Langmuir and Freundlich adsorption equations. The Langmuir model can be expressed mathematically as follows:

$q_{e}=q_{m} \frac{K_{L} C_{e}}{1+K_{L} C_{e}}$

where $q_{m}$ is the maximum adsorption capacity of the adsorbent, and it corresponds to the monolayer surface coverage $(\mathrm{mg} / \mathrm{g}), \mathrm{K}_{\mathrm{L}}$ is Langmuir constant represents the adsorption affinity $(\mathrm{L} / \mathrm{mg})$.

The Freundlich equation is also one of the most popular two-parameters isotherm model. This equation describes the adsorption behavior in heterogeneous systems. The mathematical expression of Freundlich model is given as follows:

$q_{e}=K_{F} C_{e}^{1 / n}$

here, $K_{F}$ is the Freundlich parameter associated with the adsorption affinity $\left((\mathrm{mg} / \mathrm{g}) \cdot(\mathrm{mg} / \mathrm{L})^{-\mathrm{n}}\right)$ and $n$ is a parameter that characterizes the system heterogeneity [35].

The plots of experimental adsorption data with Langmuir and Freundlich equations are given in Figs. 8-12. The parameters of Langmuir and Freundlich equations obtained from the fitting of the experimental results are summarized in Table 3. From Figs. 8-12 it can be seen that temperature has a positive influence on the amount of crystal violet adsorbed by the adsorbents. When the temperature increases, the adsorption capacity of adsorbents increased. With the increase of temperature, the interaction between the surface of adsorbents and crystal violet molecules become stronger, and more molecules of dye were attached to the surface of adsorbents leading to the increase of adsorption capacity of the adsorbents. All of the parameters of Langmuir equation are reasonable and consistent with the physical meaning of each parameter.

The value of $K_{F}$ increase as the adsorption temperature increased as seen in Table 3, suggests that at higher temperature the permeability of crystal violet onto the surface of the adsorbent is enhanced due to the greater contribution of kinetic energy. This supported by the 
(a)

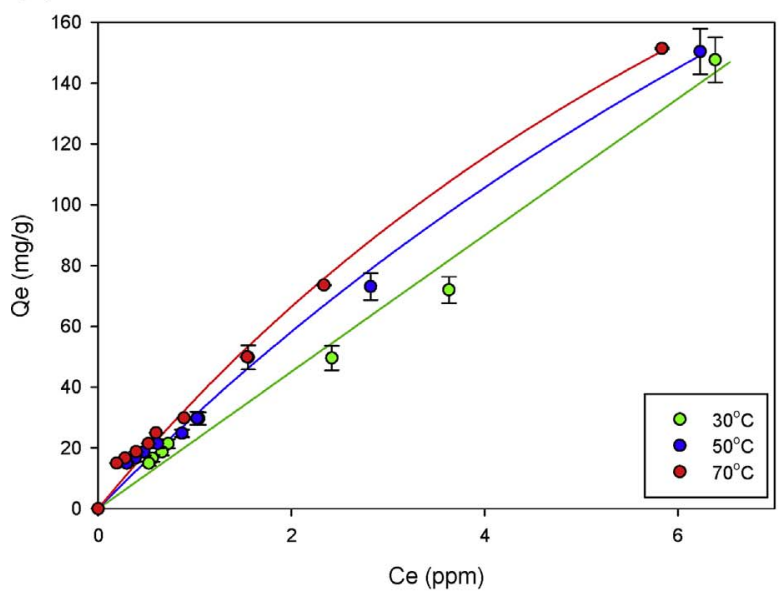

(b)

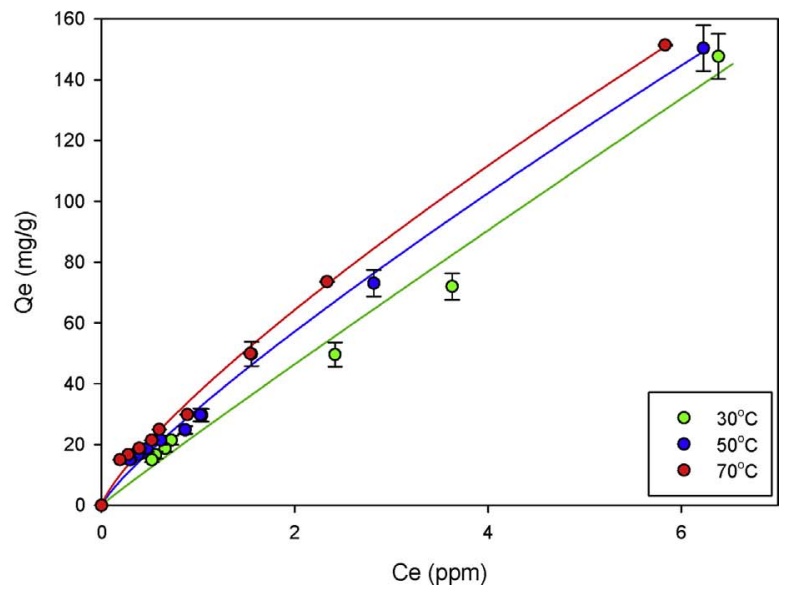

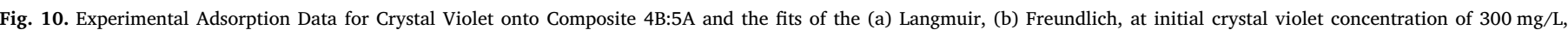
temperature 30,50 , and $70{ }^{\circ} \mathrm{C}$. (For interpretation of the references to colour in this figure legend, the reader is referred to the web version of this article.)

(a)

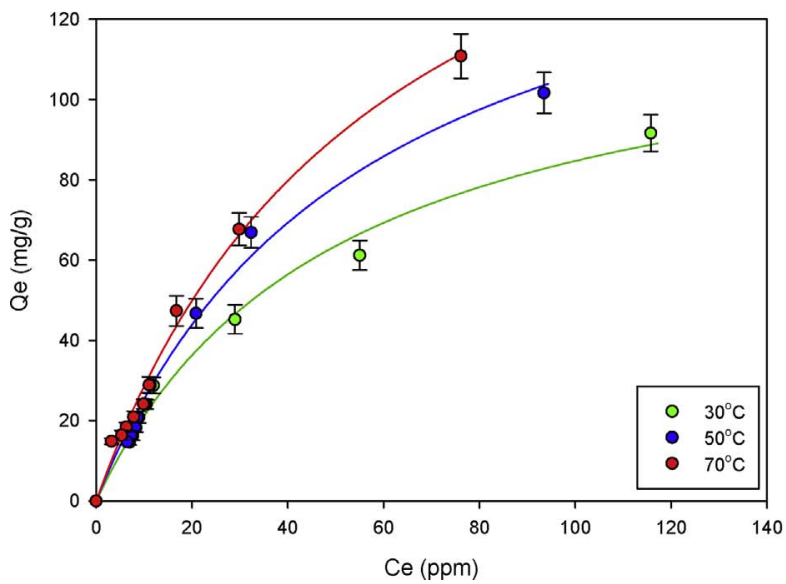

(b)

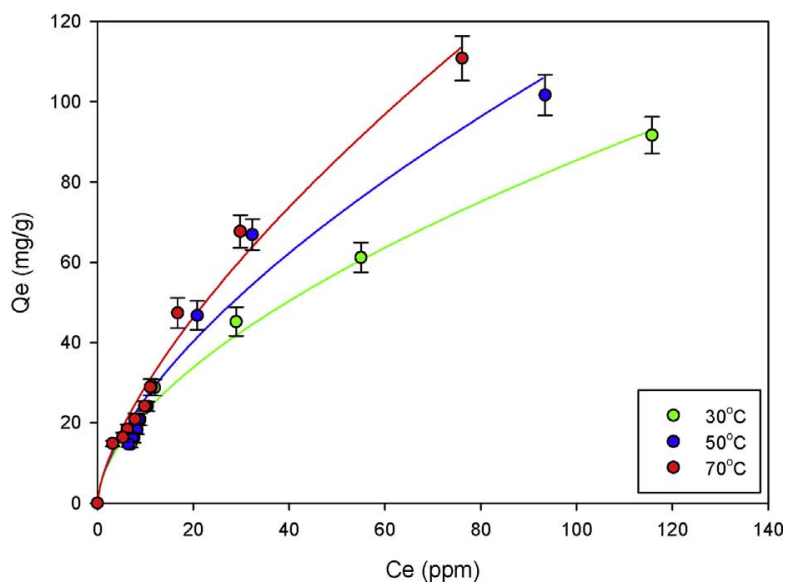

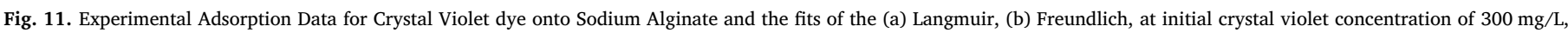
temperature 30,50 , and $70{ }^{\circ} \mathrm{C}$. (For interpretation of the references to colour in this figure legend, the reader is referred to the web version of this article.)

(a)

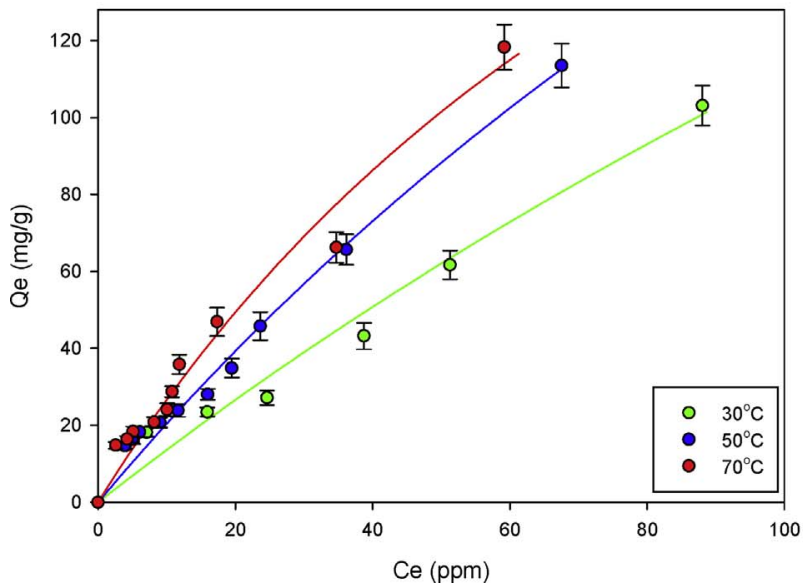

(b)

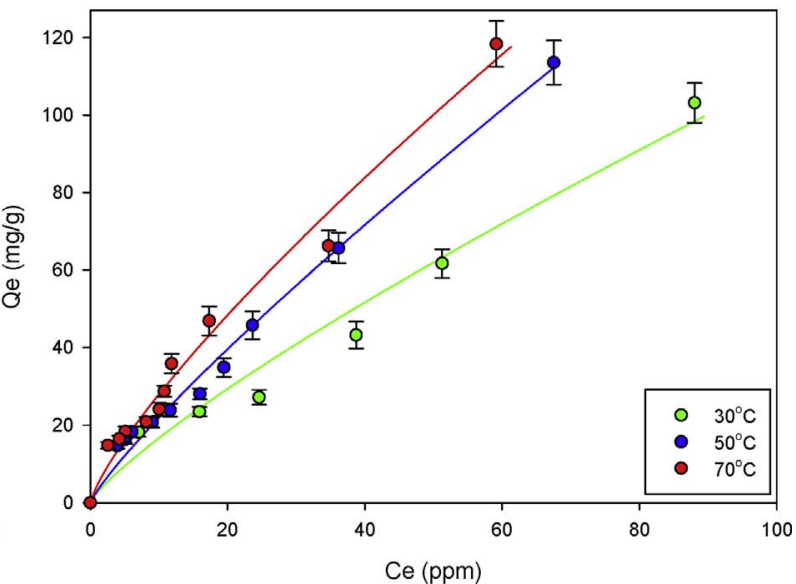

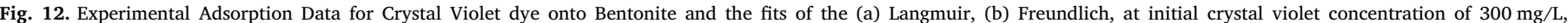
temperature 30,50 , and $70{ }^{\circ} \mathrm{C}$. (For interpretation of the references to colour in this figure legend, the reader is referred to the web version of this article.) 
Table 3

Langmuir and Freundlich Parameters of Isotherm Adsorption between Crystal Violet at initial concentration of $300 \mathrm{mg} / \mathrm{L}$ with Bentonite, Alginate and Composites.

\begin{tabular}{|c|c|c|c|c|c|c|c|c|c|}
\hline \multirow[t]{3}{*}{ Adsorbent } & \multicolumn{9}{|c|}{ Langmuir Isotherm } \\
\hline & \multicolumn{3}{|l|}{$K_{L}(\mathrm{~L} / \mathrm{mg})$} & \multicolumn{3}{|l|}{$q_{\max }(\mathrm{mg} / \mathrm{g})$} & \multicolumn{3}{|l|}{$R^{2}$} \\
\hline & $30^{\circ} \mathrm{C}$ & $50{ }^{\circ} \mathrm{C}$ & $70^{\circ} \mathrm{C}$ & $30{ }^{\circ} \mathrm{C}$ & $50^{\circ} \mathrm{C}$ & $70{ }^{\circ} \mathrm{C}$ & $30^{\circ} \mathrm{C}$ & $50{ }^{\circ} \mathrm{C}$ & $70{ }^{\circ} \mathrm{C}$ \\
\hline Bentonite (B) & 0.0025 & 0.0041 & 0.0084 & 459.6011 & 523.5270 & 541.9624 & 0.9513 & 0.9850 & 0.9733 \\
\hline Alginate (A) & 0.0200 & 0.0201 & 0.1036 & 127.1875 & 158.8212 & 218.9595 & 0.9899 & 0.9834 & 0.9908 \\
\hline 2B:5A & 0.0438 & 0.0608 & 0.0648 & 263.1415 & 323.9668 & 378.3974 & 0.9775 & 0.9932 & 0.9977 \\
\hline $3 B: 5 A$ & 0.0251 & 0.0854 & 0.1279 & 308.8336 & 378.9189 & 466.3858 & 0.9702 & 0.9755 & 0.9770 \\
\hline 4B:5A & 0.0050 & 0.0322 & 0.0965 & 462.6072 & 555.8119 & 601.9339 & 0.9837 & 0.9955 & 0.9912 \\
\hline \multirow[t]{3}{*}{ Adsorbent } & \multicolumn{9}{|c|}{ Freundlich Isotherm } \\
\hline & \multicolumn{3}{|c|}{$K_{F}\left((\mathrm{mg} / \mathrm{g})(\mathrm{L} / \mathrm{mg})^{-\mathrm{n}}\right)$} & \multicolumn{2}{|l|}{$n$} & \multicolumn{4}{|l|}{$R^{2}$} \\
\hline & $30{ }^{\circ} \mathrm{C}$ & $50{ }^{\circ} \mathrm{C}$ & $70^{\circ} \mathrm{C}$ & $30^{\circ} \mathrm{C}$ & $50^{\circ} \mathrm{C}$ & $70^{\circ} \mathrm{C}$ & $30^{\circ} \mathrm{C}$ & $50^{\circ} \mathrm{C}$ & $70^{\circ} \mathrm{C}$ \\
\hline Bentonite (B) & 2.5435 & 3.0493 & 4.4969 & 1.2251 & 1.2685 & 1.2710 & 0.9643 & 0.9898 & 0.9829 \\
\hline Alginate (A) & 5.9991 & 6.1570 & 6.4547 & 1.7339 & 1.8142 & 1.8285 & 0.9914 & 0.9941 & 0.9869 \\
\hline $2 \mathrm{~B}: 5 \mathrm{~A}$ & 14.2955 & 17.0558 & 17.8241 & 1.4082 & 1.4580 & 1.5452 & 0.9972 & 0.9779 & 0.9921 \\
\hline $3 B: 5 A$ & 18.5869 & 25.3562 & 33.2873 & 1.3654 & 1.4333 & 1.5101 & 0.9873 & 0.9940 & 0.9921 \\
\hline $4 \mathrm{~B}: 5 \mathrm{~A}$ & 23.8229 & 29.5136 & 36.3399 & 1.0386 & 1.0743 & 1.2821 & 0.9844 & 0.9935 & 0.9954 \\
\hline
\end{tabular}

randomness degree parameter, that is $n$, the increases in $n$ value as the temperature increased indicate higher random motion of the solute (crystal violet). Meanwhile, in the different context, the $n$ value decreases as the mass ratio of bentonite in the composite increased. Suggests that the sodium alginate is incorporated with bentonite hence resulted in more homogeneous surface sites. The $n$ value also indicates the surface area of the adsorbent, where higher $\mathrm{n}$ value indicates the higher surface area. Based on Table 3, alginate has largest $n$ value. However, it has lower adsorption capacity. The reason is that the composites can trap crystal violet dye molecules better than alginate and bentonite due to the complex layer that formed through the combination of bentonite-alginate.

The results indicate that increasing the temperature facilitates the penetration of crystal violet onto composite thus chemisorption was dominant in this case. The maximum adsorption capacity (based on Langmuir model) at the highest investigated temperature $\left(70{ }^{\circ} \mathrm{C}\right)$ is decreasing in the trend of Alginate $<2 \mathrm{~B}: 5 \mathrm{~A}<3 \mathrm{~B}: 5 \mathrm{~A}$ $<$ Bentonite < 4B:5A, where the value is 218.9595, 378.3974, $466.3858,541.9624$, and $601.9339 \mathrm{mg} / \mathrm{g}$, respectively. The adsorption capacity trend based on Freundlich model is Bentonite $<$ Alginate $<2 \mathrm{~B}: 5 \mathrm{~A}<3 \mathrm{~B}: 5 \mathrm{~A}<4 \mathrm{~B}: 5 \mathrm{~A}$, where the value is $4.4969,6.4547,17.8241,33.2873$, and $36.3399(\mathrm{mg} / \mathrm{g})(\mathrm{L} / \mathrm{mg})^{-\mathrm{n}}$, respectively. The composite, especially 4B:5A, has higher adsorption capacity than that of alginate and bentonite.

\subsection{Thermodynamics study}

The extensive thermodynamic properties for the adsorption of crystal violet onto various adsorbents are calculated as Gibbs energy change $\left(\Delta \mathrm{G}^{0}, \mathrm{~kJ} / \mathrm{mol}\right)$, enthalpy change $\left(\Delta \mathrm{H}^{0}, \mathrm{~kJ} / \mathrm{mol}\right)$, and entropy change $\left(\Delta S^{0}, \mathrm{~kJ} / \mathrm{mol} \mathrm{K}\right)[36,37]$. The adsorption process is favorable (spontaneous) if the value of $\Delta G^{0}$ is negative. According to DebyeHuckel limiting law for neutral or weak charges adsorbates, the value of $\Delta \mathrm{G}^{0}$ can be calculated as:

$\Delta \mathrm{G}^{0}=-R T \ln K_{L}$

where $R$ is the gas constant with the value of $8.314 \mathrm{~J} / \mathrm{mol} \mathrm{K}, T$ is the absolute temperature $(\mathrm{K})$, and $K_{L}$ is the Langmuir constant $(\mathrm{L} / \mathrm{mol})$. The relationship between $\Delta \mathrm{G}^{0}$ with $\Delta \mathrm{H}^{0}$ and $\Delta \mathrm{S}^{0}$ is expressed as:

$\Delta \mathrm{G}^{0}=\Delta \mathrm{H}^{0}-T \Delta \mathrm{S}^{0}$

Substitution of Eq. (6) to Eq. (7) gives $\ln K_{L}=-\frac{\Delta \mathrm{H}^{0}}{R T}+\frac{\Delta \mathrm{S}^{0}}{R}$

The value of $\Delta \mathrm{H}^{0}$ and $\Delta \mathrm{S}^{0}$ can be obtained from the slope and interception from the plot of $\ln K_{L}$ against $1 / T$.

The calculated thermodynamic parameters values are tabulated in Table 4. The $\Delta G^{0}$ value is negative for all systems, indicates that the adsorption process is spontaneous [38]. The increase in temperature leads to higher negative $\Delta \mathrm{G}^{0}$ value. Hence the adsorption process was favorable at a higher temperature. The positive value of $\Delta \mathrm{H}^{0}$ for all systems indicates that the adsorption process is endothermic. Meanwhile, the positive value of $\Delta S^{0}$ for all system reflects the increased randomness at the solid-solution interface during adsorption. This also implies that the adsorption is irreversible. Therefore regeneration of the adsorbent is improbable [39].

\subsection{Removal of crystal violet dye from a real or simulated wastewater}

To study the potential application of the composites for the removal of crystal violet from industrial wastewater, the adsorption experiment was also conducted using simulated wastewater. The simulated wastewater contains $\mathrm{NaCl}, \mathrm{NaCO}_{3}, \mathrm{Na}_{2} \mathrm{~S}_{2} \mathrm{O}_{3}, \mathrm{Na}_{2} \mathrm{SO}_{3}, \mathrm{Na}_{2} \mathrm{SO}_{4}, \mathrm{CuSO}_{4}, \mathrm{KCl}$, $\mathrm{K}_{2} \mathrm{CO}_{3}, \mathrm{KF}, \mathrm{K}_{2} \mathrm{SO}_{4}, \mathrm{NH}_{4} \mathrm{Cl}$, chloramine, urea, tartrate, and crystal violet. The concentration of each chemical in simulated wastewater were

Table 4

Thermodynamic Parameters for Crystal Violet Dye Adsorption by Using Bentonite, Alginate and Composites.

\begin{tabular}{|c|c|c|c|c|}
\hline Adsorbent & $\mathrm{T}\left({ }^{\circ} \mathrm{C}\right)$ & $\Delta \mathrm{G}^{0}(\mathrm{~kJ} / \mathrm{mol})$ & $\Delta \mathrm{H}^{0}(\mathrm{~kJ} / \mathrm{mol})$ & $\Delta \mathrm{S}^{0}(\mathrm{~kJ} / \mathrm{mol} \mathrm{K})$ \\
\hline \multirow[t]{3}{*}{ Bentonite (B) } & 30 & -17.4600 & \multirow[t]{3}{*}{26.0718} & \multirow[t]{3}{*}{0.1432} \\
\hline & 50 & -19.9410 & & \\
\hline & 70 & -23.2214 & & \\
\hline \multirow[t]{3}{*}{ Alginate (A) } & 30 & -22.7010 & \multirow[t]{3}{*}{34.7900} & \multirow[t]{3}{*}{0.1874} \\
\hline & 50 & -24.2121 & & \\
\hline & 70 & -30.3889 & & \\
\hline \multirow[t]{3}{*}{ 2B:5A } & 30 & -24.6768 & \multirow[t]{3}{*}{8.5756} & \multirow[t]{3}{*}{0.1100} \\
\hline & 50 & -27.1859 & & \\
\hline & 70 & -29.0502 & & \\
\hline \multirow[t]{3}{*}{ 3B:5A } & 30 & -23.2735 & \multirow[t]{3}{*}{35.5292} & \multirow[t]{3}{*}{0.1949} \\
\hline & 50 & -28.0987 & & \\
\hline & 70 & -30.9901 & & \\
\hline \multirow[t]{3}{*}{ 4B:5A } & 30 & -19.2070 & \multirow[t]{3}{*}{64.2619} & \multirow[t]{3}{*}{0.2761} \\
\hline & 50 & -25.4782 & & \\
\hline & 70 & -30.1864 & & \\
\hline
\end{tabular}




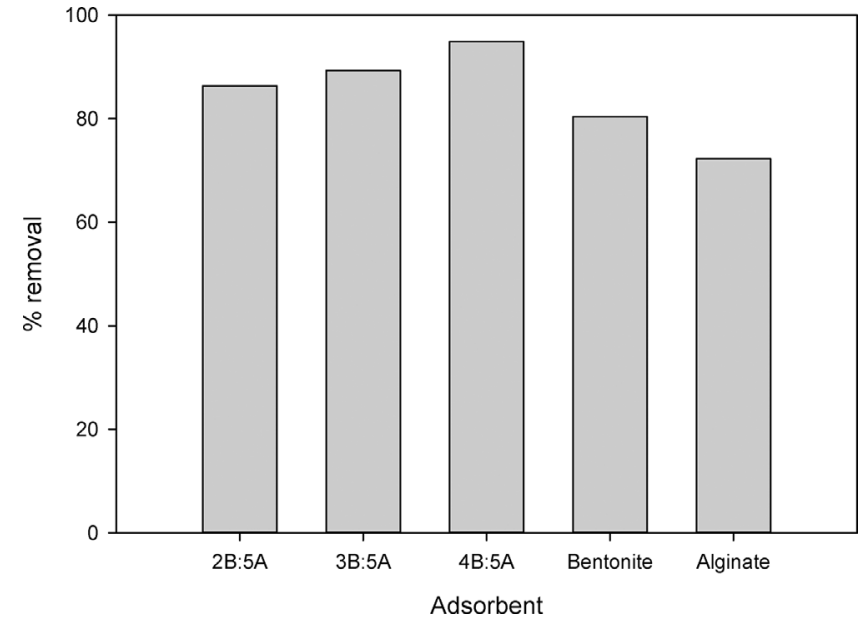

Fig. 13. Removal of crystal violet from simulated wastewater. (For interpretation of the references to colour in this figure legend, the reader is referred to the web version of this article.)

$100 \mathrm{ppm}$, while for the crystal violet was $300 \mathrm{ppm}$. The experimental result of the adsorption of crystal violet from simulated wastewater is depicted in Fig. 13. High percent removal of crystal violet indicates that the composite $(4 \mathrm{~B}: 5 \mathrm{~A})$ has potential application in industrial scale wastewater treatment.

\section{Conclusion}

Bentonite - alginate composites were synthesized from acid - activated bentonite and sodium alginate. Based on the FTIR and XRD analysis indicated that the alginate molecules did not intercalate to silicate layers of bentonite, the bonding between alginate and bentonite only through the electrostatic interaction between positively charged of bentonite with carboxyl group of sodium alginate. The pseudo-first and pseudo-second order equations were employed to correlate the adsorption kinetic results, and pseudo-second order could represent the experimental data better than pseudo-first order. Chemisorption is dominant and controls the adsorption as rate-limiting step. Both Langmuir and Freundlich equation could represent the adsorption data well with reasonable and consistent values of parameters.

\section{Acknowledgement}

Financial support from Indonesia Ministry of Research, Technology, and Higher Education through Fundamental Research - University Research Priority scheme is highly appreciated.

\section{Appendix A. Supplementary data}

Supplementary data associated with this article can be found, in the online version, at https://doi.org/10.1016/j.jece.2017.10.057.

\section{References}

[1] M. Otero, F. Rozada, L.F. Calvo, A.I. Gracía, A. Morán, Elimination of organic water pollutants using adsorbents obtained from sewage sludge, Dye Pigm. 57 (2003) 55-65.

[2] B.J. Brüschweiler, S. Küng, D. Bürgi, L. Muralt, E. Nyfeler, Identification of nonregulated aromatic amines of toxicological concern which can be cleaved from azo dyes used in clothing textiles, Regul. Toxicol. Pharmacol. 69 (2014) 263-272.

[3] M.A. Chowdhury, M. Joshi, B.S. Butola, Thermochromic colorants in textile applications, J. Eng. Fiber Fabrics 9 (2014) 107-123.

[4] R.S. Raveendra, P.A. Prashanth, R.H. Krishna, N.P. Bhagya, B.M. Nagabhushana, H.R. Naika, K. Lingaraju, H. Nagabhushana, B.D. Prasad, Synthesis, structural characterization of nano ZnTiO3 ceramic: an effective azo dye adsorbent and antibacterial agent, J. Am. Ceram. Soc. 2 (2014) 357-365.

[5] E. Eren, B. Afsin, Investigation of a basic dye adsorption from aqueous solution onto raw and pre-treated bentonite surfaces, Dye Pigm. 76 (2008) 220-225.

[6] K.A. Adegoke, O.S. Bello, Dye sequestration using agricultural wastes as adsorbents, Water Res. Ind. 12 (2015) 8-24.

[7] L.G. Rushing, M.C. Bowman, Determination of gentian violet in animal feed, human urine, and wastewater by high pressure liquid chromatography, J. Chromatogr. Sci. 18 (2016) 224-232.

[8] A. Akbari, J.C. Remigy, P. Aptel, Treatment of textile dye effluent using a polyamide-based nanofiltration membrane, ChemEngPro 41 (2002) 601-609.

[9] S. Banerjee, M.C. Chattopadhyaya, Adsorption characteristics for the removal of a toxic dye, tartrazine from aqueous solutions by a low cost agricultural by-product, Arab. J. Chem. 10 (2017) S1629-S1638.

[10] S. Raghu, C.A. Basha, Chemical or electrochemical techniques followed by ion exchange, for recycle of textile dye wastewater, J. Hazard. Mater. 149 (2007) 324-330.

[11] B. Shi, G. Li, D. Wang, C. Feng, H. Tang, Removal of direct dyes by coagulation: the performance of preformed polymeric aluminum species, J. Hazard. Mater. 143 (2007) 567-574.

[12] N. Al-Bastaki, Removal of methyl orange dye and Na2so4 salt from synthetic waste water using reverse osmosis, Chem. Eng. Process. Process Intensif. 43 (2004) 1561-1567.

[13] I. Arslan, I.A. Balcioğlu, D.W. Bahnemann, Advanced chemical oxidation of reactive dyes in simulated dyehouse effluents by ferrioxalate-Fenton/UV-A and TiO2/UV-A processes, Dye Pigm. 47 (2000) 207-218.

[14] C. Wang, A. Yediler, D. Lienert, Z. Wang, A. Kettrup, Ozonation of an azo dye C.I. Remazol Black 5 and toxicological assessment of its oxidation products, Chemosphere 52 (2003) 1225-1232.

[15] I.M. Banat, P. Nigam, D. Singh, R. Marchant, Microbial decolorization of textiledye-containing effluents: a review, Bioresour. Technol. 58 (1996) 217-222.

[16] R.W. Martin, C.R. Baillod, J.R. Mihelcic, Low-temperature inhibition of the activated sludge process by an industrial discharge containing the azo dye acid black 1 , Water Res. 39 (2005) 17-28.

[17] Z. Carmen, S. Daniela, Textile organic dyes - characteristics, polluting effects and Separation/Elimination procedures from industrial effluents - a critical overview, in: T. Puzyn (Ed.), Organic Pollutants Ten Years After the Stockholm Convention Environmental and Analytical Update, InTech, China, 2012, pp. 55-86.

[18] W.K. Jo, R.J. Tayade, Recent developments in photocatalytic dye degradation upon irradiation with energy-efficient light emitting diodes, Chin. J. Catal. 35 (2014) 1781-1792.

[19] X.H. Sun, X.L. Chang, W.Q. Tuo, D. Wang, K.F. Li, Performance comparison of dyesensitized solar cells by using different metal oxide- coated TiO2 as the photoanode, AIP Adv. 4 (2014) 1-7.

[20] R. Sivashankar, A.B. Sathya, K. Vasantharaj, V. Sivasubramanian, Magnetic composite an environmental super adsorbent for dye sequestration - a review, Environ. Nanotechnol. Monitor. Manage. 1-2 (2014) 36-49.

[21] T.D. Pham, T.T. Do, V.L. Ha, T.H.Y. Doan, T.A.H. Nguyen, T.D. Mai, M. Kobayashi, Y. Adachi, Adsorptive removal of ammonium ion from aqueous solution using surfactant-modified alumina, Environ. Chem. 14 (2017) 327-337.

[22] T.D. Pham, M. Kobayashi, Y. Adachi, Adsorption characteristics of anionic azo dye onto large $\alpha$-alumina beads, Colloid Polym. Sci. 293 (2015) 1877-1886.

[23] T.D. Pham, M. Kobayashi, Y. Adachi, Adsorption of polyanion onto large alpha alumina beads with variably charged surface, Adv. Phys. Chem. (2014) 9 (Article ID 460942).

[24] T.D. Pham, M. Kobayashi, Y. Adachi, Adsorption of anionic surfactant sodium dodecyl sulfate onto alpha alumina with small surface area, Colloid Polym. Sci. 293 (2015) 217-227.

[25] P. Komadel, J. Madejová, Acid activation of clay minerals, in: F. Bergaya, B.K.G. Theng, G. Lagaly (Eds.), Handbook of Clay Science, Elsevier Ltd., 2006, pp. 263-287.

[26] S. Brunauer, P.H. Emmett, E. Teller, Adsorption of gases in multimolecular layers, J. Am. Chem. Soc. 60 (1938) 309-319.

[27] K.S.W. Sing, Adsorption methods for the characterization of porous materials, Adv Colloid Interface Sci. 76-77 (1998) 3-11.

[28] P.C.C. Faria, J.J.M. Orfao, M.F.R. Pereira, Adsorption of anionic and cationic dyes on activated carbons with different surface chemistries, Water Res. 38 (2004) 2043-2052.

[29] R. Ahmad, A. Mirza, Sequestration of heavy metal ions by Methionine modified bentonite/Alginate (Meth-bent/Alg): A bionanocomposite, Groundw. Sustain. Dev. 1 (2015) 50-58.

[30] S.N.A. Rahim, A. Sulaiman, F. Hamzah, K.H.K. Hamid, M.N.M. Rodhi, M. Musa, N.A. Edama, Enzymes encapsulation within calcium alginate-clay beads: characterization and application for cassava slurry saccharification, Procedia Eng. 68 (2013) 411-417.

[31] F. Adzmi, S. Meon, M.H. Musa, N.A. Yusuf, Preparation, characterisation and viability of encapsulated Trichoderma harzianum UPM40 in alginate-montmorillonite clay, J. Microencapsulation 29 (2012) 205-210.

[32] S. Barreca, S. Orecchio, A. Pace, The effect of montmorillonite clay in alginate gel beads for polychlorinated biphenyl adsorption: isothermal and kinetic studies, Appl. Clay Sci. 99 (2014) 220-228.

[33] K. Bahranowski, A. Gawel, A. Klimek, A. Michalik-Zym, B.D. Napruszewska, M. Nattich-Rak, M. Rogowska, E.M. Serwicka, Influence of purification method of Na-montmorillonite on textural properties of clay mineral composites with TiO2 nanoparticles, Appl. Clay Sci. 140 (2017) 75-80.

[34] F.P. Yesi, Y.H. Sisnandy, F.E. Ju, S. Soetaredjo, Ismadji, Adsorption of acid blue 129 from aqueous solutions onto raw and surfactant modified bentonite: the application of temperature dependent form of adsorption isotherms, Adsorp. Sci. Technol. 28 (2010) 847-868. 
[35] E. Nathaniel, A. Kurniawan, F.E. Soetaredjo, S. Ismadji, Organo-bentonite for the adsorption of $\mathrm{Pb}$ (II) from aqueous solution: temperature dependent parameters for several adsorption equations, Desalin. Water Treat. 36 (2011) 280-288.

[36] L. Deng, Y. Su, H. Su, X. Wang, X. Zhu, Biosorption of copper (II) and lead (II) from aqueous solutions by nonliving green algae Cladophora $\mathrm{f}$ ascicularis: equilibrium, kinetics and environmental effects, Adsorption 12 (2006) 267-277.

[37] Y. Liu, Is the free energy change of adsorption correctly calculated? J. Chem. Eng.
Data 54 (2009) 1981-1985.

[38] V. Padmavathy, Biosorption of nickel(II) ions by baker's yeast: kinetic, thermodynamic and desorption studies, Bioresour. Technol. 99 (2008) 3100-3109.

[39] W.S.W. Ngah, M. Hanafiah, Adsorption of copper on rubber (Hevea brasiliensis) leaf powder: kinetic, equilibrium, and thermodynamic studies, Biochem. Eng. J. 39 (2008) 521-530 